\title{
COMPUTATIONAL PREDICTION OF THE MECHANICAL PROPERTIES OF A 2D TRIAXIALLY BRAIDED COMPOSITE
}

MICHAL VAŠIČCKK

CTU Prague, Technická 4, Tel +420 22435 2498, Fax: +420 22435 2500, E-mal: michal.vasicek@fs.cvut.cz

\section{SHRNUTI}

Článek představuje vývoj nových numerických modelů kompozitních materiálů na mezi-úrovni. Modely jsou určeny k predikci mechanických vlastností v tahu, tlaku, smyku a impaktním zatížení různých konfigurací tri-axiálně pleteného uhlíkového kompozitu, přičemž využívá znalosti materiálových vlastností vlákna a matrice a zvolené geometrie pletení. Představené výsledky jsou porovnány s měřením na vzorcích materiálu a vykazují dobrou úroveň shody. Modely Ize využít mimo predikce materiálových vlastností v detailních analýzách porušení laminátu.

KLIČCVÁ SLOVA: KOMPOZITNÍ MATERIÁL, PREDIKTIVNII METODY, TŘÍŠTĚNÍ, SPH, MKP

\section{ABSTRACT}

The paper presents the development of new numerical models of composite materials at the meso-scale. Models are used to predict the mechanical properties in tension, compression, shear and axial impact load of different configurations of triaxial braided carbon composite, applying knowledge of the material properties of the fibers and matrix, and the chosen geometry of the braid. The presented results are compared with measurements from samples of the material and show a good level of correlation. In addition to the prediction of material properties, models can be used for detailed analyses of damage evolution and failure of the laminate.

KEYWORDS: COMPOSITE MATERIAL, PREDICTIVE METHOD, CRUSHING, SPH, FEM

\section{INTRODUCTION}

For decades the use of composite materials has been seen as a suitable way to produce lightweight constructions in the aerospace industry. It has also gained importance in the automotive industry, particularly after the European Commission announced in late 2006 that it is working on a proposal for legally binding measures and limits for $\mathrm{CO}_{2}$ emissions. Manufacturers realized the necessity for developing new body concepts, utilizing the knowledge of lightweight design and advanced computational tools (i.e. topological optimization) with the objective of significant body mass reduction and consequent fulfilling of the $\mathrm{CO}_{2}$ limit. From this point of view the composites are very promising, but the state-of-the-art in the field of automotive design does not guarantee a feasible result without excessive mechanical testing on the level of coupons, subsystems and assemblies.

Such process can be extremely expensive if we consider the variability of composite material in reinforcement and matrix material, their volume fractions, geometry of the reinforcement and layup (stacking sequence of the laminate), which all determine its mechanical properties. The alternative approach would be the analytical or numerical prediction of the mechanical properties, which enables determination of promising (or suspected as optimal) materials for specific applications and their testing. The prediction of elastic and strength properties and resistance in axial crushing of triaxially braided carbon/epoxy laminates is the objective of this study.

\section{MAIN SECTION}

\subsection{BRAID ARCHITECTURE}

A 2D braided preform consists of two sets of yarns passing over and under each other. These yarns are called braiding yarns (bias). A triaxially braided preform is a modification of this pattern, which adds a third yarn in the longitudinal direction (Figure 1). This yarn is called an axial yarn and basically improves the dimensional stability of the preform and mechanical properties in the longitudinal direction. One half of the angle between braiding yarns $\varphi$ is one of the basic geometric parameters and braids can be manufactured in the range of $30^{\circ}-70^{\circ}$. A part can be designed as a closed section profile with variable angle across the length. 


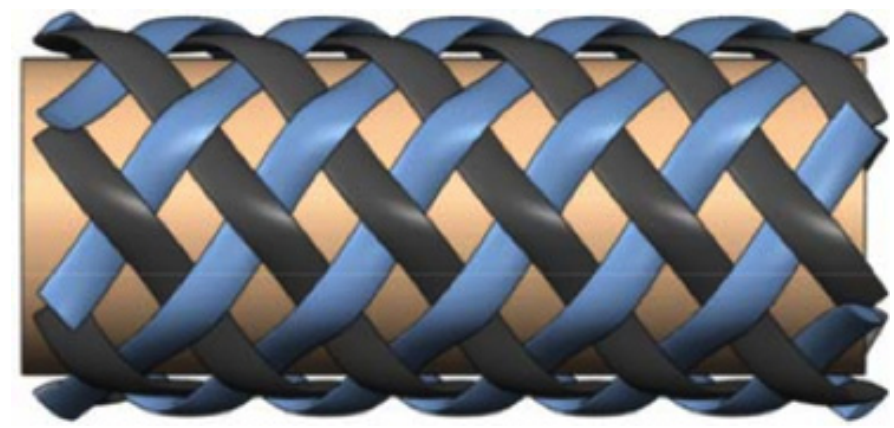

OBRÁZEK 1: Triaxiální pletený preform (vpravo) v porovnání s obecným FIGURE 1: A triaxially braided preform compared to a simple braid.

\subsection{COMPUTATIONAL MODEL FOR PREDICTION} OF STIFFNESS AND STRENGTH

The manufacturing processes (braiding, forming, infusion) strongly influence the mechanical properties of the fibrous composite material. With the aim of covering the influence of braiding and forming on the stiffness and strength, a meso-scale FEM model was created and analyzed using ESI's Pamcrash Explicit solver. The model utilizes the output of braiding process simulation [1], performed with a 1D representation of the yarns. These yarn trajectories are transformed into a shell of yarns with width and thickness corresponding to the fiber diameter $(7 \mu \mathrm{m})$ and its content in the yarn $(24 \mathrm{~K})$. The virtual preform is then compressed by a tool on the mandrel to obtain a required thickness of the impregnated layer. The final configuration of the yarns is shown in Figure 2.

These yarns are overlaid by a box of 3D elements (8-node hexa), which represents the matrix. The final steps are the definition of the constraints (TIED) between the yarn nodes and matrix elements to establish a union, and therefore force transmission between all parts of the laminate and definition

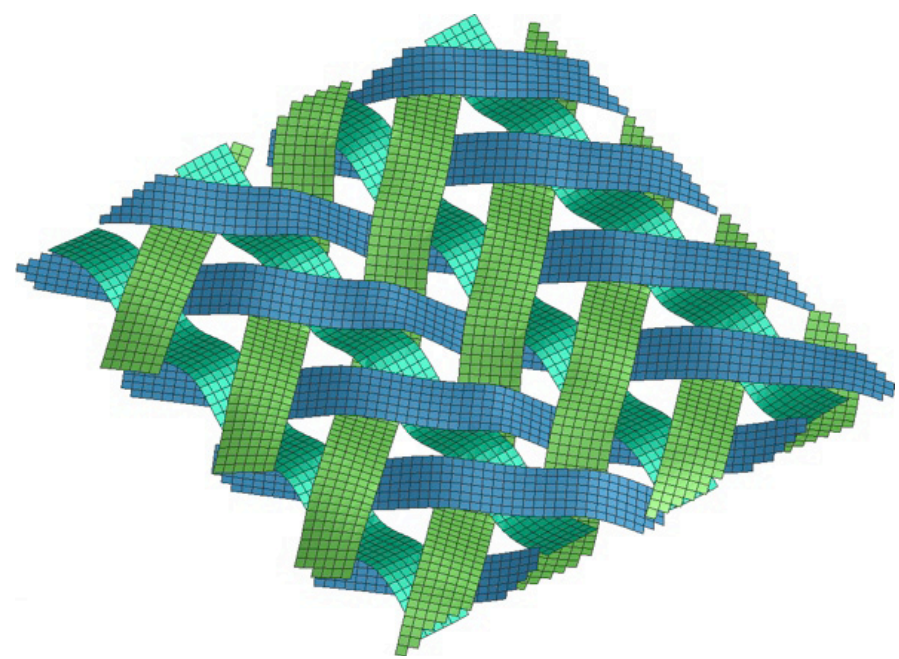

OBRÁZEK 2: Model reprezentující svazky vláken pleteného $45^{\circ}$ triaxiálního kompozitu

FIGURE 2: View of the yarns in a 45 deg. braid

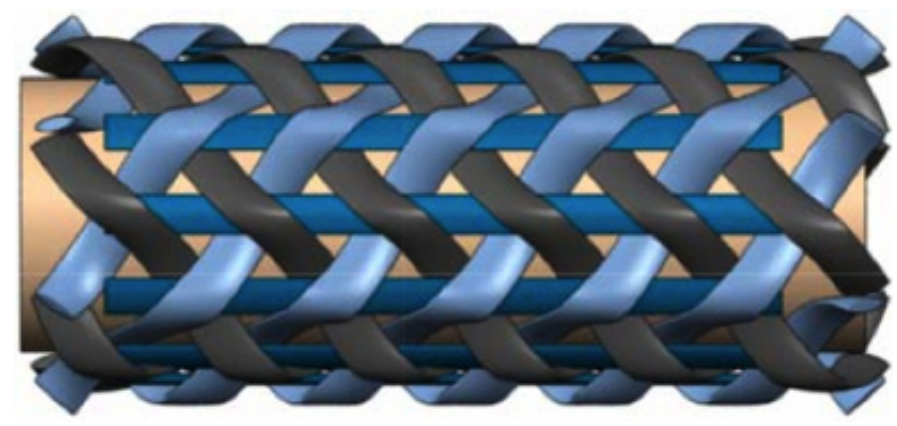

of (symmetric type 33) contacts between yarns themselves, and yarns to matrix.

The mechanical properties of carbon fiber (TOHO Tenax STS $24 \mathrm{~K})$ yarns are defined by the Multilayered Shell material which utilizes the Unidirectional Composite Global Ply Model. Although its main purpose is description of the properties of the unidirectional laminate, where we assume some fiber/ matrix volume content, here it describes the pure fiber material including its ultimate strength in tension, compression and shear. The matrix is defined as an ElasticPlastic Material with Damage and Failure. Both damage and failure are activated.

The model was tested for its ability to predict mechanical properties of a laminate in tension and shear at the level of a representative unit cell (RUC, the smallest volume over which a measurement can be made that will yield a value representative of the whole, see Figure 3 ) and a general sample, with approx. 20x larger area. This sample contains more geometrical imperfections (positions of yarns) and therefore reflects the structure of real parts more accurately. Both RUC and general samples represent one layer of the preform.

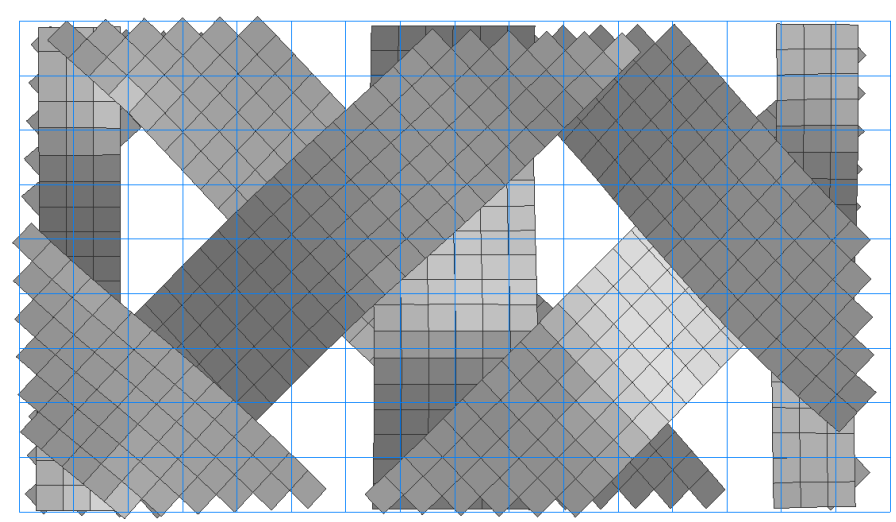

OBRÁZEK 3: Geometrie RUC a její FE model

FIGURE 3: Geometry of the RUC model and its representation in the FE model 


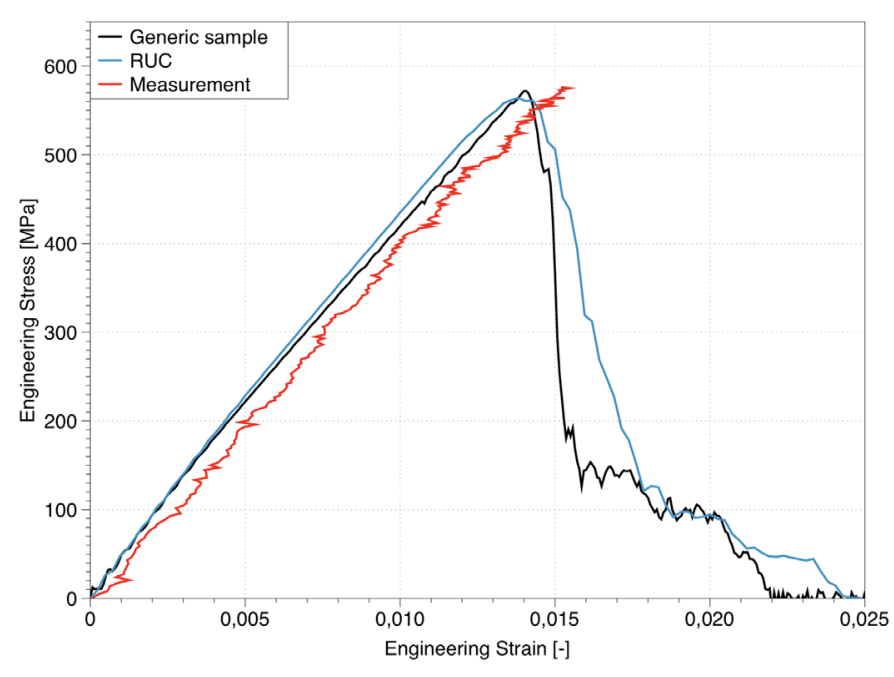

OBRÁZEK 4: Závislost poměrné deformace na napětí v podélném tahu FIGURE 4: Stress-strain characteristics in longitudinal tension

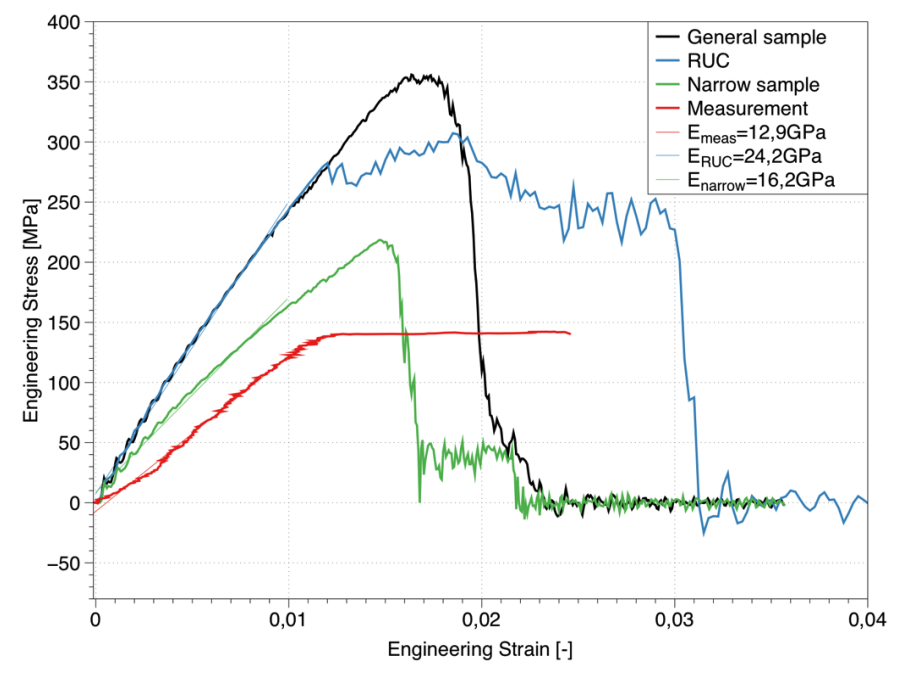

OBRÁZEK 6: Závislost poměrné deformace na napětí v příčném tahu FIGURE 6: Stress-strain characteristics in transverse tension

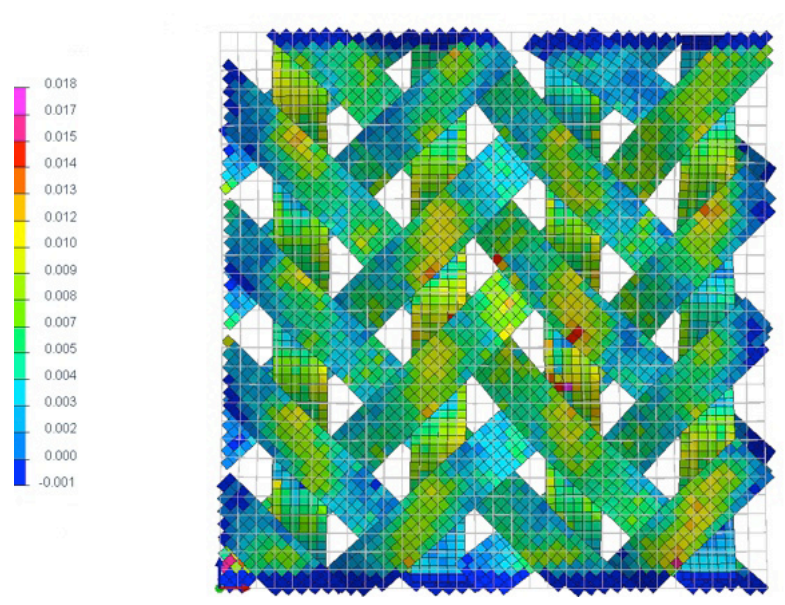

OBRÁZEK 5: Rozložení prvního hl. napětí ve vláknech a redukovaného (Von Mises) napětí v matrici príi podélném tahu v okamžiku vzniku trhliny FIGURE 5: Contour of the first principal strain on the yarns and Von Mises stress on the matrix in longitudinal tension at the point of first rupture

\subsubsection{LONGITUDINAL TENSION}

The results of longitudinal tension are shown in Figure 4. Both models (RUC and the general sample) show very good agreement with measurements of modulus, and the general sample in strength as well. The modulus predicted by the RUC model is higher than the measured one, which can be substantiated by slightly different geometries of undulated axial yarns of the RUC (it contains only two axial yarns) and the general sample, which contains more yarns and more geometrical imperfections and undulations. The imperfections become the stress concentrators under load and initiate rupture (Figure 5).

\subsubsection{TRANSVERSE TENSION}

The results of the transverse tension test and comparison with measurements show significant discrepancy in the modulus and strength (Figure 6). The results were revised and compared with the analytical results (using Classical Lamination Theory and
Bringing Model [2]), which lead to a modulus $\mathrm{E}_{\mathrm{T}}=16.7 \mathrm{GPa}$. The tested coupon was $150 \mathrm{~mm}$ long (free length) and $25.4 \mathrm{~mm}$ wide. If we imagine a coupon of such aspect ratio, we find that none of the braiding yarns were directly loaded (clamped between both sides of the test machine). On the other hand, the simulations were carried out on the models which have at least one pair of braiders clamped (Figure 7, left), so the load was carried by them. This assumption led to a modification of the general sample to correspond with the tested sample (see Narrow sample in Figure 6 and its geometry in Figure 7, right).

The alternative test procedure for the transverse tension makes use of a notched sample and shows significantly higher strength [3]. Under this assumption, the results of the narrow samples are considered to be correct and future tests should be performed on the notched samples to validate it. 


\subsubsection{LONGITUDINAL AND TRANSVERSE SHEAR}

The next set of tests and simulations was aimed at prediction of the shear moduli and strength. The physical tests were examined according to the three rail shear test standards (ASTM D 4255/D $4255 \mathrm{M}$ ) in both longitudinal and transverse orientation of the laminate (Figure 8). Simulations were performed on the models representing only one half of the fixture and on the geometry of a general sample, which had a free width of approx. $15 \mathrm{~mm}$, which was $20 \mathrm{~mm}$ in the case of physical tests. The simulations of the RUC contained only its corresponding geometry.

The results of simulations and the recorded data are displayed in Figure 9 and Figure 10. The simulations predicted shear moduli in both directions accurately whilst the ability to predict shear strength seems to be reasonable only in the case of the general sample. It covers the effects of geometrical imperfections precisely and therefore also the strengths.
TABULKA 1: Vlastnosti vlákna

TABLE 1: Properties of the fiber

$\begin{array}{lcccc}\text { Fiber } & \begin{array}{c}\text { Nensity } \\ {\left[\mathrm{g} \mathrm{cm}^{-3}\right]}\end{array} & \begin{array}{c}\text { Normal } \\ \text { modulus } \\ {[\mathrm{GPa}]}\end{array} & \begin{array}{c}\text { Tensile } \\ \text { strength } \\ {[\mathrm{MPa}]}\end{array} & \begin{array}{c}\text { Ultimate } \\ \text { tensile strain } \\ {[\%]}\end{array} \\ \begin{array}{l}\text { STS40 F13 } \\ \text { 1600tex }\end{array} & 1,77 & 242 & 4240 & 1,77\end{array}$
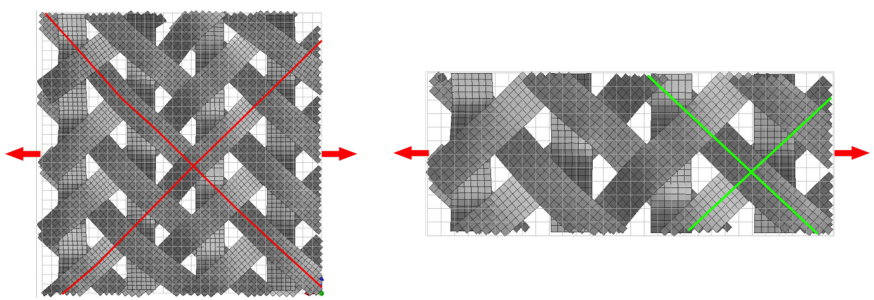

OBRÁZEK 7: Obecný vzorek se znázorněním zatížených pramenů (červeně), vlevo. Modifikovaný vzorek, vpravo.

FIGURE 7: General sample with loaded yarns in red, left. Modified sample on the right.

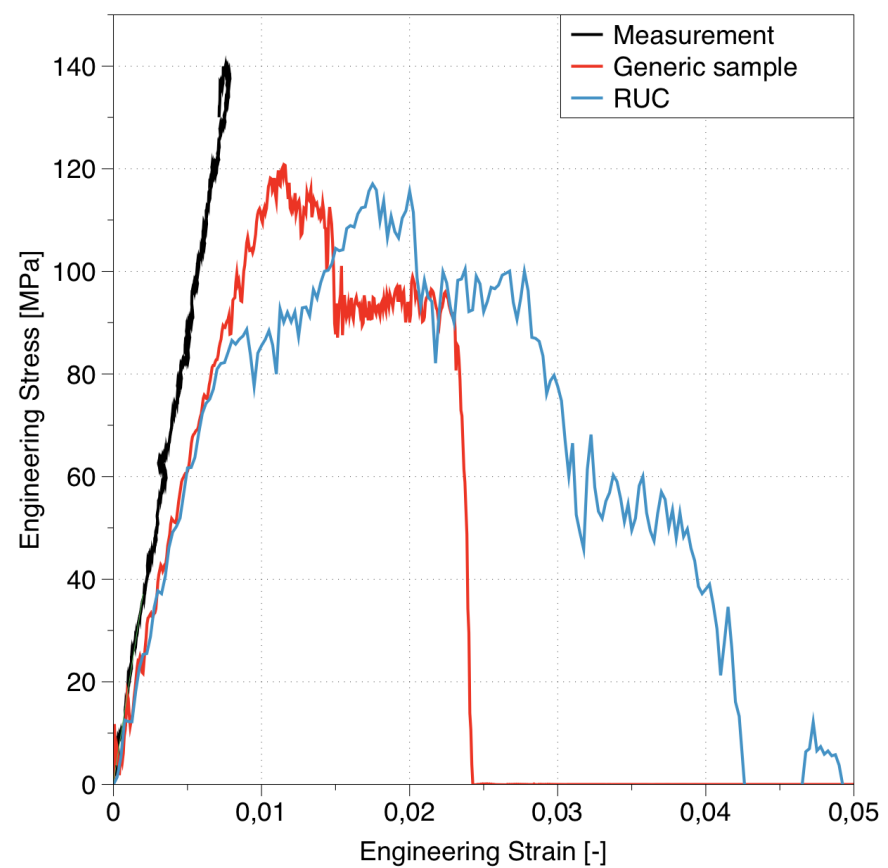

OBRÁZEK 9: Podélný smyk FIGURE 9: Longitudinal shear
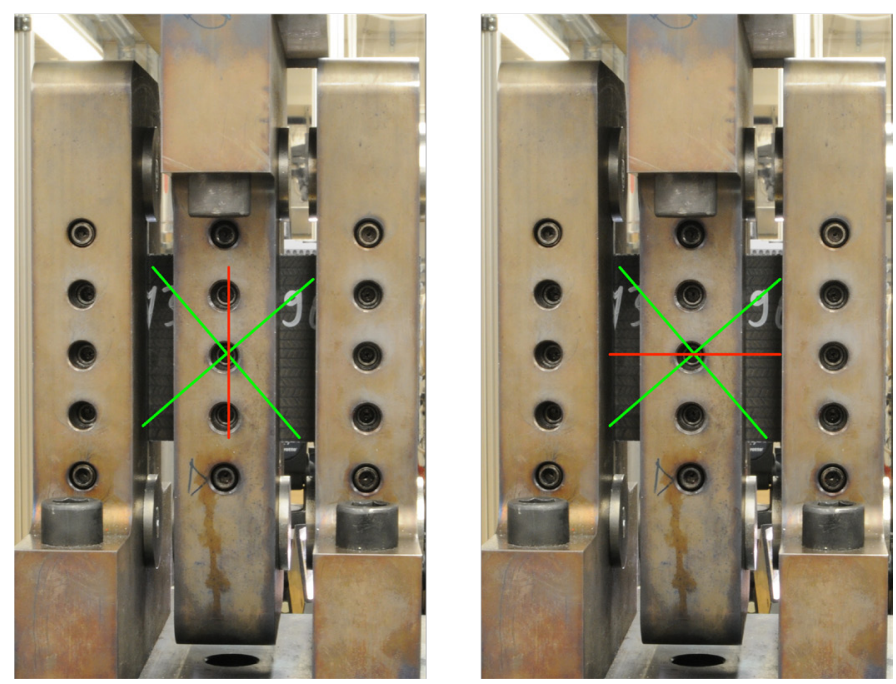

OBRÁzEK 8: Pozice vzorku při zkoušce smykem. Podélná na levém snímku, příčná na pravém snímku.

FIGURE 8: Arrangement of laminate in the shear tests. Longitudinal on the left, transverse on the right

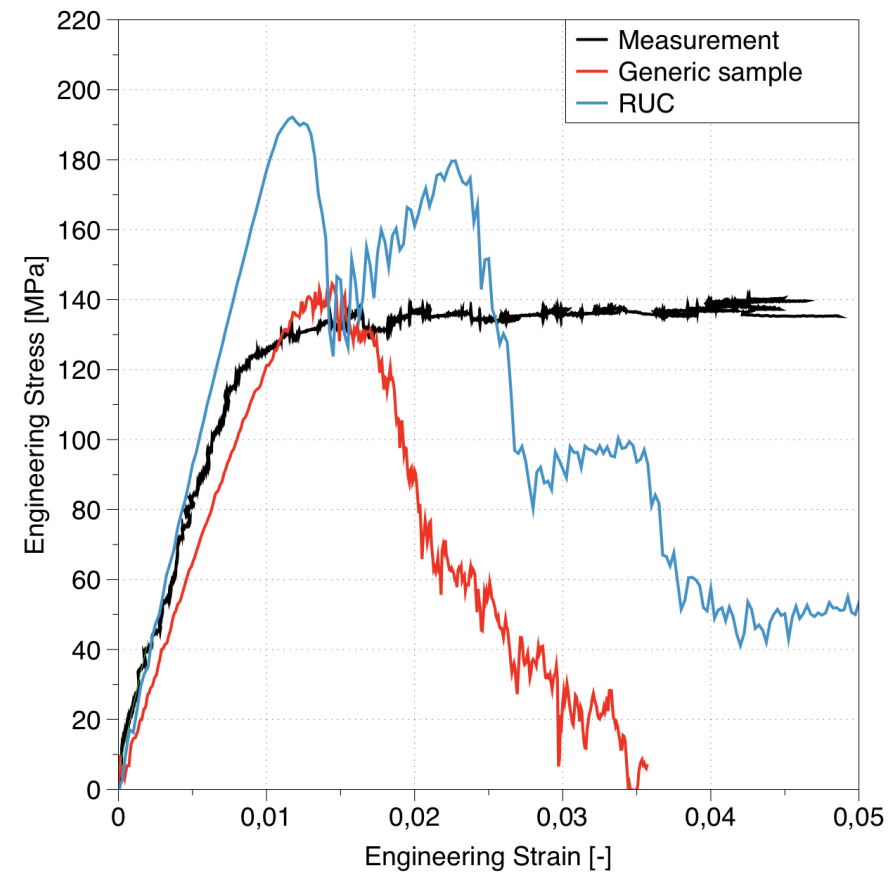

OBRÁZEK 10: Příčný smyk

FIGURE 10: Transverse shear 


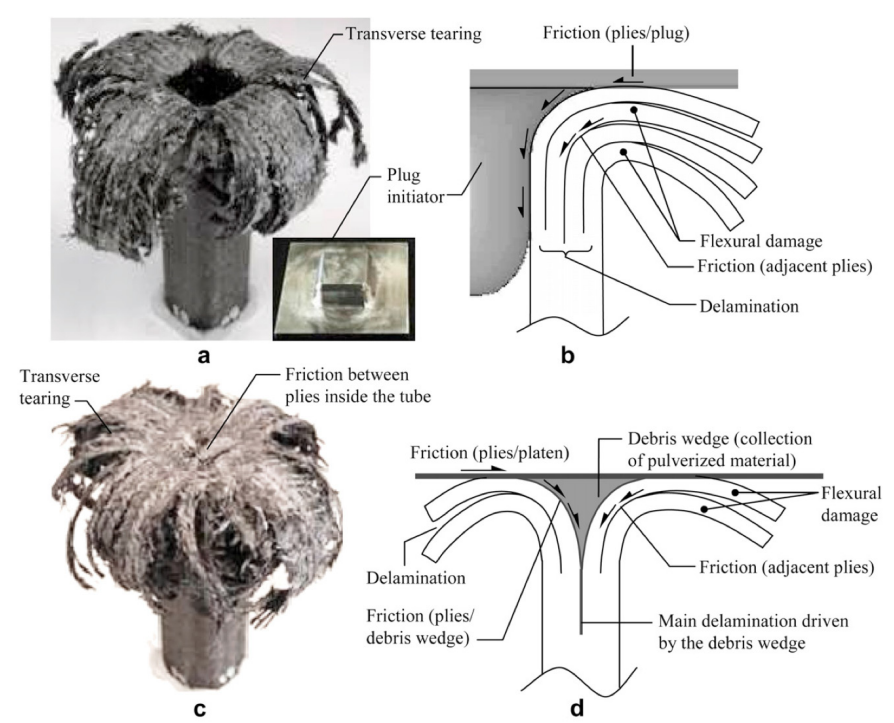

OBRÁZEK 11: Mechanismus axiálního tř̌štění kompozitu [4] FIGURE 11: Mechanism of a composite's axial crushing [4]

Comparison of the measured and numerically predicted values of moduli and strengths are shown in Table 2.

\subsection{PREDICTION OF BEHAVIOR UNDER AXIAL CRUSHING}

One of the major benefits of the carbon composite materials is an extraordinary ability to absorb energy under axial crushing. The axial crushing is caused by micro-fragmentation of buckled or bent fibers and delamination of the layers of laminate. The fragmentation is usually initiated by excessive loading of the free-edge of laminate, which can be done by geometric modification of that edge (tapering) or by the specific shape of the plug (Figure 11).

Despite this benefit of the material, utilization of structures made from it is limited by the price of carbon reinforcement material and the ability to simulate axial crushing using CAE methods.

TABULKA 2: Porovnání naměřených hodnot a numericky predikovaných TABLE 2: Comparison of the measured and numerically predicted values

\begin{tabular}{lcccc} 
& CLT & FEM RUC & FEM General & Measurement \\
\hline $\mathrm{E}_{\mathrm{L}}[\mathrm{GPa}]$ & 37.2 & 45.4 & 43.8 & 39.3 \\
\hline $\mathrm{E}_{\mathrm{T}}[\mathrm{GPa}]$ & 16.8 & 24.2 & 16.2 & 12.9 \\
\hline $\mathrm{X}_{\mathrm{L}}[\mathrm{MPa}]$ & & 652 & 572 & 576 \\
\hline $\mathrm{X}_{\mathrm{T}}[\mathrm{MPa}]$ & & 303 & 222 & 148 \\
\hline $\mathrm{G}_{\mathrm{LT}}[\mathrm{GPa}]$ & & 12.5 & 13.2 & 12.5 \\
\hline $\mathrm{G}_{\mathrm{TL}}[\mathrm{GPa}]$ & 21.2 & 19.1 & 12.9 & 15.4 \\
\hline $\mathrm{X}_{\mathrm{LT}}[\mathrm{GPa}]$ & & 157 & 120 & 140 \\
\hline $\mathrm{X}_{\mathrm{TL}}[\mathrm{GPa}]$ & & 205 & 144 & 141 \\
\hline
\end{tabular}

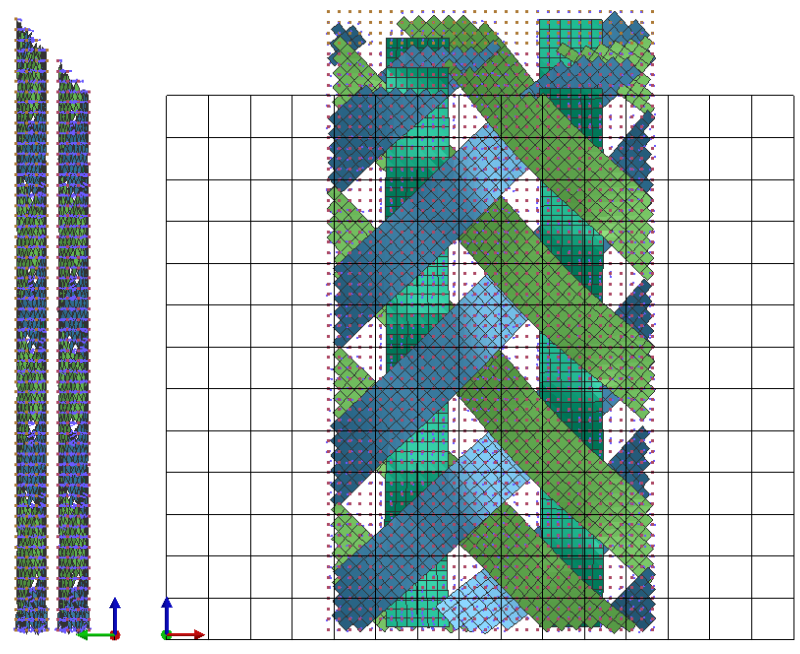

OBRÁZEK 12: Konfigurace simulace tříštění laminátu FIGURE 12: Configuration of the laminate crushing simulation

A new modeling approach was investigated. Structural analyses using FEM is the state-of-the-art with respect to crashworthiness and allows the solving of many nonlinear problems (i.e. crash test simulations). The new approach is based on a combination of FEM and SPH methods. The numerical models operate on the same level of geometry as used in the previous section, but the 3D elements representing the matrix are replaced by SPH elements (using the same material model and modifying contact between 2D and SPH elements to non-symmetric type 34), whereby the problem of excessive mesh distortion is eliminated. The suggested approach was tested on the narrow sample of the 2-layer braid with respect to the boundary conditions of testing methodology presented by [5]. The laminate is fully restrained (ODOF) on the bottom end, supported on the sides by rigid walls and impacted by the rigid surface with constant velocity (1DOF).

The experiments were performed on tube samples of diameter $67.5 \mathrm{~mm}$ with a tapered edge (trigger) and display a typical rectangular force-displacement characteristic of fibrous composites in crushing. These characteristics were transformed into the crushing stress-displacement relationship (Figure 13), allowing comparison with different samples.

The simulation was performed on the smaller sample (Figure 12) with the same trigger type and the mean value of the crushing stress was compared (Figure 14). The resulting characteristic is also rectangular and crushing stress is comparable to the measured one, but does not correspond in the crushing initiation phase, where the physical sample oscillates under the impacting weight. The SPH elements 


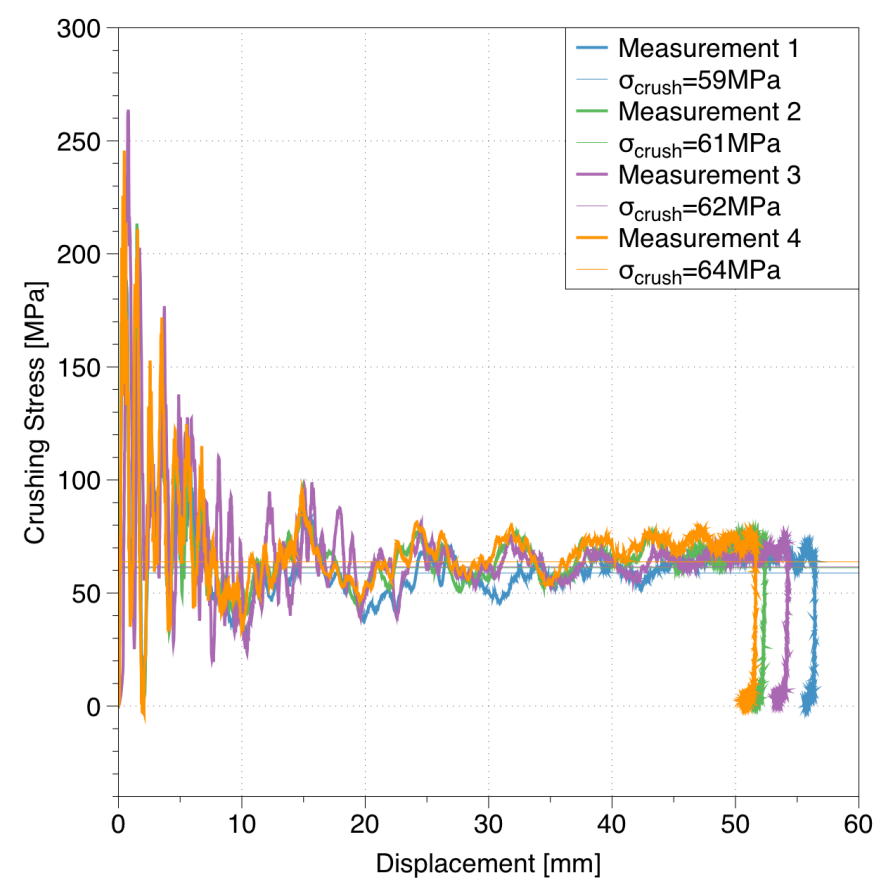

OBRÁZEK 13: Výsledné charakteristiky testů tříštění FIGURE 13: Results of the tube crushing tests

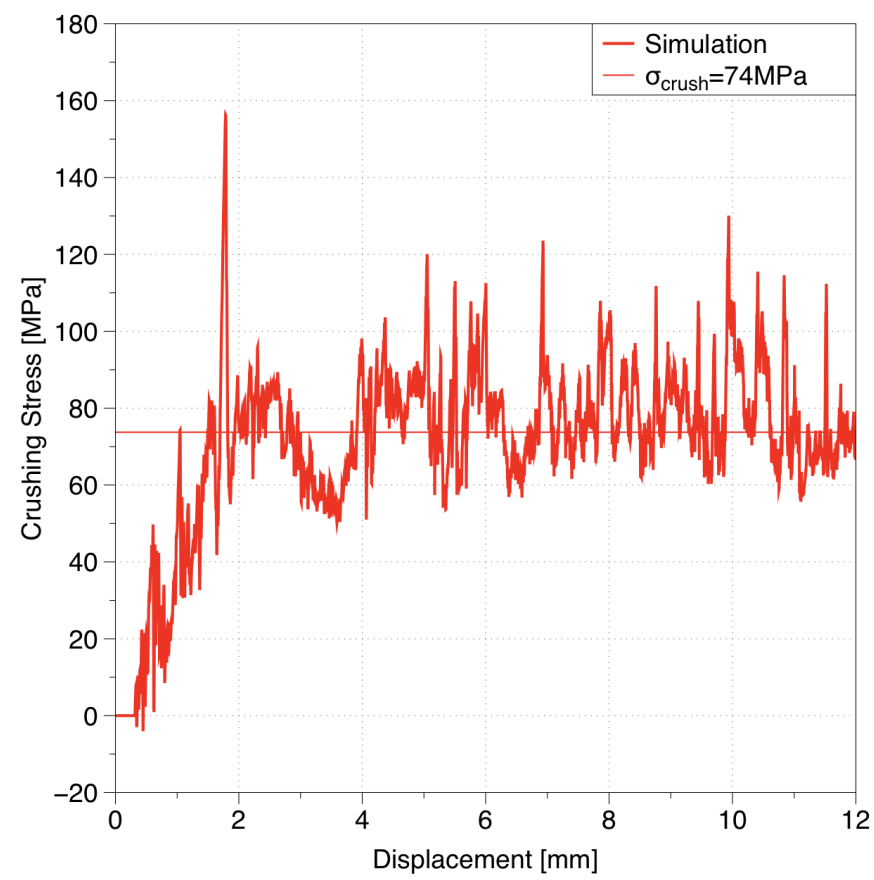

OBRÁZEK 14: Výsledný průběh simulace tříštění FIGURE 14: Results of the crushing simulation

damp this phenomena and the resulting crushing force increases smoothly. The proposed approach demonstrated the possibility of simulating crushing phenomena using the combined FEM and SPH model. On the other hand, the method is applicable to meso-scale samples due to much higher computational demands compared to the FEM.

\section{CONCLUSION}

The paper has presented numerical models for predicting mechanical properties in triaxially braided composite materials. Two sizes of models were tested and both of them provide reasonable results. The final validation was performed for a $45^{\circ}$ braid only. The work aims at a future ability to predict mechanical properties of the various triaxially braided composites and their utilization in crash applications, and therefore a novel approach of axial crushing was developed. The model combines advantages of the FEM (existing material models of composites, computationally effective) and SPH method (mesh-free, large deformation without causing mesh distortion) to accurately simulate the effect of crushing, which is geometrically strongly nonlinear. Future work will be aimed at generalization of the predictive models, so that it will cover the whole range of braid configurations.

\section{ACKNOWLEDGEMENTS}

The author would like to thank the Technology Agency of the Czech Republic (Centres of Competence, project \# TE01020020 Josef Božek Competence Centre for Automotive Industry), the Department of Science, Research and Art Baden-Wuerttemberg (AZ 32-729.85-1/90) and the Technology-Cluster Composites (TC2) for funding and supporting the work presented in the paper.

\section{REFERENCES}

[1] Anthony K. Pickett, Justas Sirtautas, Andreas Erber (2009). Braiding Simulation and Prediction of Mechanical Properties, Applied Composite Materials, Vol. 16, pp. 345-364, DOI 10.1007/s10443-009-9102-x

[2] Zheng-Ming Huang (2012). Simulation of the mechanical properties of fibrous composites by the bridging micromechanics model, Composites: Part A, Vol. 32, pp. $143-172$

[3] Lee W. Kohlman, Justin L. Bail, Gary D. Roberts, Jonathan A. Salem, Richard E. Martin, Wieslaw K. Binienda (2012). A notched coupon approach for tensile testing of braided composites, Composites: Part A, Vol. 43, pp. 1680-1688

[4] Carla McGregor, Reza Vaziri, Xinran Xiao (2010). Finite element modelling of the progressive crushing of braided composite tubes under axial impact, International Journal of Impact Engineering, Vol. 37, pp. 662-672

[5] S. Cauchi Savona, P.J. Hogg (2006). Investigation of plate geometry on the crushing of flat composite plates, Composite Science and Technology, Vol. 66, pp. 1639-1650 


\section{APPENDICES}

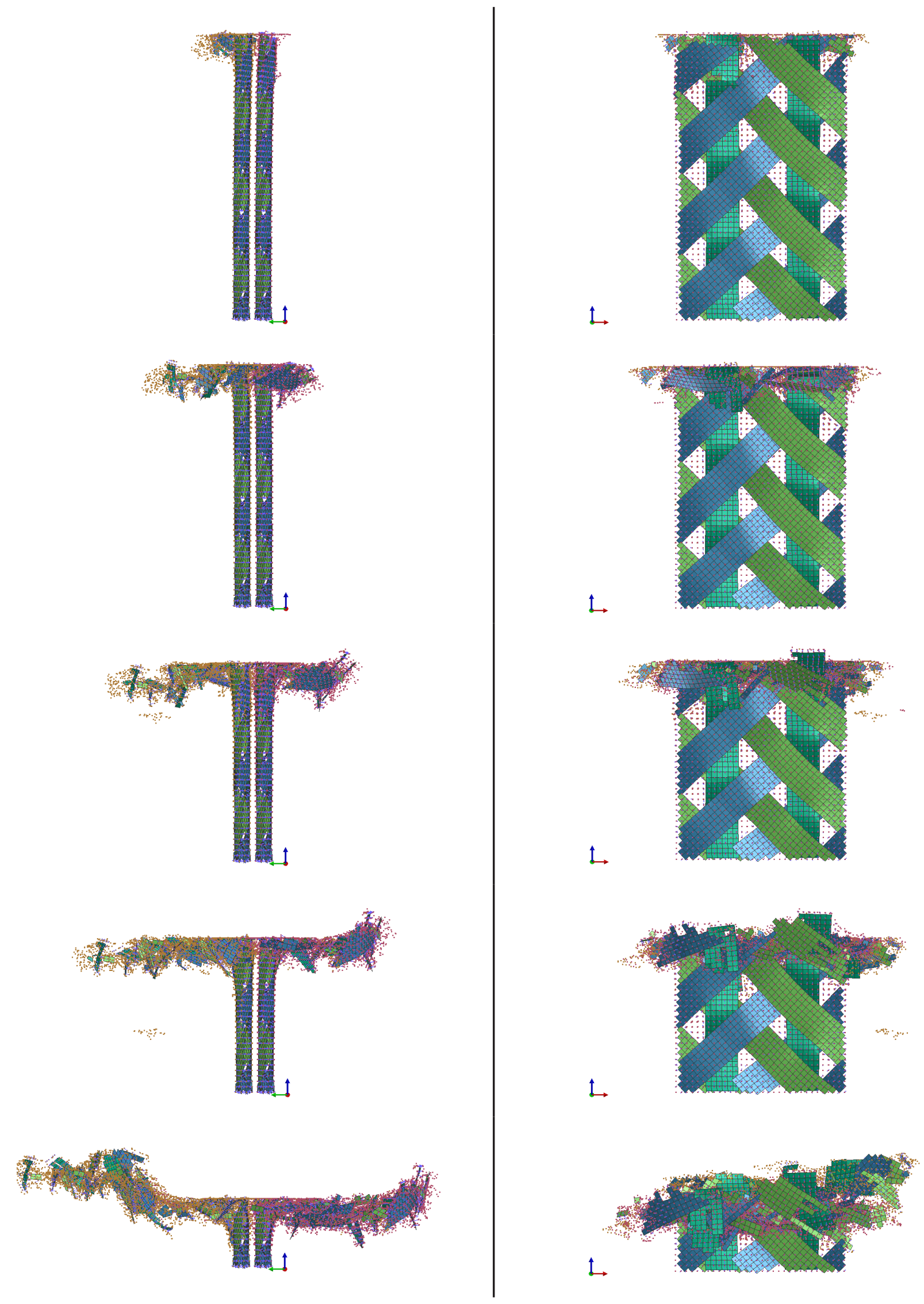

